\title{
DISPARITAS DALAM PENJATUHAN PIDANA
}

\author{
Nimerodi Gulö ${ }^{1}$, Ade Kurniawan Muharram² \\ Fakultas Hukum, Universitas Diponegoro, Semarang, Indonesia ${ }^{1}$; \\ Fakultas Hukum, Universitas Lampung, Bandar Lampung, Indonesia ${ }^{2}$ \\ gulonime@rocketmail.com
}

\begin{abstract}
The formulation of norms related to criminal threats is basically maximum. This creates a disparity in the judge's decision. This disability can cause a sense of injustice (substantive justice) for the convicted person. The formulation of the problem is, what is the factor causing the occurrence of criminal disparity in the criminal imprisonment carried out by the judge and what is the basis of the judge's judgment in deciding criminal penalties in the trial ?. The research method used is normative and empirical methods in relation to substantive justice. The results of the research show that in deciding the case the judge is subject to Article 197 of the Criminal Procedure Code, namely the judge must have his own judgment in determining the weight or severity of the sentence to be imposed on the defendant, through material evidence in court to support the conclusion in the judge's judgment. At present the judiciary in Indonesia is still using the method of sentencing based on trial hearings only. This causes a court decision issued by the judge to have a difference between one decision and another decision called criminal disparity.
\end{abstract}

\section{Abstrak}

Rumusan norma yang berkaitan dengan ancaman pidana pada dasarnya bersifat maksimum. Hal tersebut menimbulkan ruang disparitas putusan hakim. Disapritas tersebut dapat menimbulkan rasa ketidakadilan (keadilan substantif) bagi terpidana. Rumusan masalahnya adalah, apa yang menjadi faktor penyebab terjadinya disparitas pidana dalam penjatuhan pidana yang dilakukan oleh hakim dan apakah yang menjadi dasar pertimbangan hakim dalam memutus perakara pidana didalam persidangan?. Metode penelitian yang digunakan adalah metode normatif dan empiris dalam kaitannya dengan keadilan substantif. Hasil penelitian menunjukan dalam memutuskan perkara hakim tunduk pada Pasal 197 KUHAP, yaitu hakim harus memiliki pertimbangannya sendiri didalam menentukan berat atau ringannya hukuman yang akan dijatuhkan kepada terdakwa, melalui pembuktian materil dipersidangan untuk mendukung kesimpulan dalam pertimbangan hakim. Saat ini peradilan di Indonesia masih menggunakan metode penjatuhan hukuman berdasarkan pemeriksaan persidangan saja. Hal ini menyebabkan putusan pengadilan yang dikeluarkan oleh hakim terdapat perbedaan antara satu putusan dengan putusan yang lainnya yang disebut dengan disparitas pidana.

Kata kunci : disparitas, penjatuhan pidana.

\section{A. Pendahuluan}

Sistem peradilan pidana (criminal justice system) dari hukum pidana memiliki posisi sentral. Hal ini disebabkan karena keputusan dalam pemidanaan mempunyai konsekuensi yang luas, baik yang menyangkut langsung kepada pelaku tindak pidana maupun masyarakat secara luas. Dalam perannya sebagai penegakan hukum pidana, secara fungsional sistem peradilan 
pidana akan melibatkan minimal 3 (tiga) faktor yang saling terkait, yaitu faktor perundang-undangan, faktor aparat atau penegak hukum, dan faktor kesadaran hukum(Komisi Yudisial RI, 2014). Faktor perundang-undangan dalam hal ini perundang-undangan pidana, meliputi hukum pidana materil (hukum pidana substantif) maupun hukum pidana formil (hukum acara pidana). Ada dua aspek penting dalam keberhasilan penegakkan hukum pidana, yaitu isi atau hasil penegakan hukum (substantif justice) dan tata cara penegakkan hukum (procedural justice.(Komisi Yudisial RI, 2014)

Indonesia adalah negara hukum yang memberikan kebebasan pada hakim dalam memutuskan suatu perkara pidana, maksudnya adalah hakim tidak boleh mendapat intervensi dari pihak manapun. Hakim sebagai pejabat peradilan negara yang berwenang untuk menerima, memeriksa, dan memutus perkara yang dihadapkan kepadanya.Pada hakikatnya tugas hakim untuk mengadili mengandung dua pengertian, yakni menegakkan keadilan dan menegakkan hukum(Mertokusumo, 2007). Pasal 5 ayat (1) Undang-Undang Nomor 48 Tahun 2009 tentang Kekuasaan Kehakiman menyebutkan bahwa hakim wajib menggali, mengikuti, dan memahami nilai-nilai hukum dan rasa keadilan yang hidup dalam masyarakat. Pasal 8 ayat (2) menyebutkan bahwa hakim juga dapat wajib mempertimbangkan sifat baik dan jahat pada diri terdakwa selama persidangan.

Peraturan perundang-undangan pidana yang selama ini dibuat tidak memberikan pedoman pemberian pidana secara tegas yang menjadi dasar bagi hakim dalam menjatuhkan pidana kepada terdakwa. Undang-undang yang ada hanya dijadikan sebagai pedoman pemberian hukuman maksimal dan minimalnya saja. Oleh karena itu, pedoman pemberian pidana seharusnya secara tegas dicantumkan dalam Undangundang, untuk menghindari kesewenangwenangan yang dilakukan oleh hakim dalam menjatuhkan putusannya(Wijayanto, 2012). Hal inilah yang sering kali menimbulkan disparitas dalam penjatuhan pidana yang dilakukan oleh hakim.

Disparitas pidana (disparity of sentencing) adalah penerapan pidana yang tidak sama terhadap tindak pidana yang sama (same offence) atau terhadap tindaktindak pidana yang sifatnya berbahaya dapat diperbandingkan (offences of comparable seriousnees) tanpa dasar pembenaran yang jelas. Selanjutnya tanpa merujuk "legal category", disparitas pidana dapat terjadi pada penghukuman terhadap mereka yang melakukan suatu delik secara bersama(Muladi dan Barda Nawawi Arief, 1984). Disparitas pemidanaan mempunyai dampak yang dalam, karena didalamnya 
terkandung perimbangan konstitusional antara kebebasan individu dan hak Negara untuk memidana.(Muladi dan Barda Nawawi Arief, 1984)

Adanya faktor-faktor yang menjadi penyebab terjadinya disparitas pidana, tetapi pada akhirnya hakimlah yang akan menentukan terjadinya suatu disparitas pidana. Masalah disparitas pidana ini akan terus terjadi karena adanya jarak antara sanksi pidana minimal dengan sanksi pidana maksimal. Proses formulasi yang dilakukan oleh badan legislatif selaku pembentuk Undang-undang juga sangat berpengaruh pada disparitas pidana, dikarenakan tidak adanya standard untuk merumuskan sanksi pidana.

Dalam Pasal 1 ayat (11) KUHAP disebutkan bahwa putusan pengadilan adalah penryataan hakim yang diucapkan dalam sidang terbuka, yang dapat berupa pemidanaan atau bebas dari atau lepas dari segala tuntutan hukum dalam hal serta cara yang diatur didalam Undang-Undang ini. Namun masih banyak sekali putusan yang diberikan oleh hakim kepada terpidana yang belum mencapai keadilan di dalam masyarkat, karena masih banyak dijumpai ketidak sesuaian hakim dalam menjatuhkan pidana.

Harkristuti Harkrisnowo(Harkrisnowo, 2003) mengatakan bahwa :
Terjadinya disparitas pidana dalam penegakkan hukum karena adanya realita disparitas pidana tersebut, tidak heran jika publik mempertanyakan apakah hakim/pengadilan telah benar-benar melaksanakan tugasnya menegakkan hukum dan keadilan? Dilihat dari sisi sosiologis, kondisi disparitas pidana dipersepsi publik sebagai bukti ketiadaan keadilan (societal justice). Sayangnya secara yuridis formal,kondisi ini tidak dapat dianggap telah melanggar hukum. Meskipun demikian, seringkali orang melupakan bahwa elemen "keadilan" pada dasarnya harus melekat pada putusan yang diberikan oleh hakim.

Selanjutnya Harkristuti Harkrisnowo, menyatakan bahwa disparitas pidana dapat terjadi dalam beberapa kategori yaitu(Komisi Yudisial RI, 2014):

a. Disparitas antara tindak pidana yang sama;

b. Disparitas antara tindak pidana yang mempunyai tingkat keseriusan yang sama;

c. Disparitas pidana yang dijatuhkan oleh satu majelis hakim;

d. Disparitas antara pidana yang dijatuhkan oleh majelis hakim yang berbeda untuk tindak pidana yang sama.

Berdasarkan pendapat diatas dapat dipahami bahwa salah satu pembenaran disparitas pidana telah membawa hukum kita kepada keadaan yang tidak lagi sesuai 
dengan tujuan penegakkan hukum. Hukum yang semula dimaksudkan untuk menjadi penjaga keadilan, kemanfaatan sosial, dan kepastian hukum tidak lagi dapat dipenuhi secara utuh, karena dalam hal ini unsur keadilanlah yang oleh masyarakat dirasia tidak lagi dipenuhi atau diberikan oleh hakim dalam menegakkan hukum(Komisi Yudisial RI, 2014).

Sebagai contoh adanya disparitas dipaparkan putusan tindak pidana kecelakaan lalu lintas yang menyebabkan kematian di Pengadilan Negeri Metro:

\begin{tabular}{|c|c|c|c|}
\hline No & $\begin{array}{l}\text { Nomor Putusan } \\
\text { Pengadilan }\end{array}$ & $\begin{array}{l}\text { Pasal } \\
\text { yang } \\
\text { dijatuh } \\
\text { kan }\end{array}$ & $\begin{array}{c}\text { Lama } \\
\text { Huku } \\
\text { man }\end{array}$ \\
\hline 1. & $\begin{array}{l}\text { 116/PID.B/2013/ } \\
\text { PN.M }\end{array}$ & $\begin{array}{l}310 \text { ayat } \\
\text { (4) }\end{array}$ & 8 Bulan \\
\hline 2. & $\begin{array}{l}\text { 138/Pid.Sus/2013 } \\
\text { /PN.M }\end{array}$ & $\begin{array}{l}310 \text { ayat } \\
\text { (4) }\end{array}$ & 2 Bulan \\
\hline 3. & $\begin{array}{l}\text { 94/Pid.Sus/2014/ } \\
\text { PN.Met }\end{array}$ & $\begin{array}{l}310 \text { ayat } \\
\text { (4) }\end{array}$ & 3 Bulan \\
\hline 4. & $\begin{array}{l}\text { 110/Pid.B/2015/P } \\
\text { N.Met }\end{array}$ & $\begin{array}{l}310 \text { ayat } \\
\text { (4) }\end{array}$ & 4 Bulan \\
\hline 5. & $\begin{array}{l}\text { 32/Pid.B/2013/P } \\
\text { N.M }\end{array}$ & $\begin{array}{l}310 \text { ayat } \\
\text { (4) }\end{array}$ & $\begin{array}{c}6 \text { Bulan } \\
\text { dengan } \\
\text { masa } \\
\text { percoba } \\
\text { an } \\
\text { selama } \\
10 \\
\text { bulan }\end{array}$ \\
\hline
\end{tabular}

Tabel 1. Nomor Putusan Pengadilan dan Pasal yang dijatuhkan, Serta Lamanya Hukuman yang Disparitasnya Diteliti Sumber:

\section{https://www.mahkamahagung.go.id/id}

Kondisi ini sangat memperihatinkan dan menuntut semua pihak, khususnya para penegak hukum untuk meningkatkan pengertian, pemahaman dan keterampilan dalam profesinya sehingga dapat melaksanakan tugas dengan adil dan sebaikbaiknya. Dalam penyelenggaraannya pengadilan harus menggunakan ukuran yang sudah diterima oleh dunia hukum, yakni asas legalitas. Asas legalitas menjamin masyarakat terutama terdakwa atau terpidana guna menghindari kesewenangwenangan hakim dalam menetapkan perbuatan yang dapat dikatergorikan dalam suatu rumusan delik.

Adanya disparitas pidana dalam suatu sitem peradilan pidana akan menyebakan kepercayaan masyarkat pada lembaga peradilan semakin melemah dan akan menimbulkan stigma terhadap keberlangsungan hukum di Indonesia, karena itu diperlukan penelitian hukum untuk membahas lebih lanjut hal-hal yang menjadi faktor penyebab disparitas pidana didalam penjatuhan pidana. 


\section{Rumusan Masalah}

Berdasarkan latar belakang masalah yang telah diuraikan diatas, maka rumusan masalahnya yaitu "Apa yang menjadi faktor penyebab terjadinya disparitas pidana dalam penjatuhan pidana yang dilakukan oleh hakim dan apakah yang menjadi dasar pertimbangan hakim dalam memutus perakara pidana didalam persidangan?"

\section{B. Metode Penelitian}

Sistem penulisan pada jurnal ini menggunakan pendekatan yuridis normatif dan yuridis empiris. Adapun jenis dan sumber data yang terdiri dari data primer yang bersumber dari lapangan dan data sekunder bersumber dari kepustakaan. Data yang telah diperoleh kemudian dianalisis secara kulaitatif yang pokok bahsan akhirnya menuju pada suatu kesimpulan ditarik dengan metode induktif.

\section{Hasil Penelitian dan Pembahasan}

Pemidanaan diartikan sebagai tahap penetapan sanksi dan juga tahap pemberian sanksi dalam hukum pidana. Kata "pidana" pada umumnya diartikan sebagai hukuman, sedangkan "pemidanaan” diartikan sebagai penghukuman. Doktrin membedakan hukum pidana materil dan hukum pidana formil. J.M. Van Bemmelen menjelaskan kedua hal tersebut sebagai berikut :
Hukum pidana materil terdiri atas tindak pidana yang disebut berturut-turut, peraturan umum yang dapat diterapkan terhadap perbuatan itu, dan pidana yang diancamkan terhadapan perbuatan itu. Hukum pidana formil mengatur bagaimana cara pidana seharusnya dilakukan dan menentukan tata tertib yang harus diperhatikan pada kesempatan itu.

Mr. Tirtamidjaja menjelaskan hukum pidana materiil dan hukum pidana formil sebagai berikut :

a. Hukum pidana materiil adalah kumpulan aturan hukum yang menentukan pelanggaran pidana, menetapkan syaratsyarat bagi pelanggaran pidana untuk dapat dihukum, menunjukkan orang yang dapat dihukum dan menetapkan hukuman atas pelanggaran pidana.

b. Hukum pidana formil adalah kumpulan aturan hukum yang mengaturcara mempertahankan hukum pidana materiil terhadap pelanggaranyang dilakukan oleh orang-orang tertentu, atau dengan kata lain,mengatur cara bagaimana hukuman pidana materiil diwujudkansehingga diperoleh keputusan hakim serta mengatur caramelaksanakan keputusan hakim(Marpaung, 2005).

Berdasarkan pendapat diatas, hukum pidana materil berisi larangan atau perintah jika tidak terpenuhi diancam sanksi, sedangkan hukum pidana formil adalah 
aturan hukum yang mengatur cara menjalankan dan melaksanakan hukum pidana materil.

Tujuan pemidanaan ini merupakan bagian yang sangat mendasar dan penting dalam kehidupan hukum pidana di Indonesia bahkan diseluruh negara. Menurut Barda Nawawi Arief tujuan dari kebijakan pemidanaan yaitu menetapkan suatu pidana tidak terlepas dari tujuan politik kriminal. Dalam arti keseluruhannya yaitu perlindungan masayarakat untuk mencapai kesejahteraan. Oelh karena itu untuk menjawab dan mengetahui tujuan serta fungsi pemidanaan, maka tidak terlepas dari teori-teori tentang pemidanaan yang ada (Muladi, 1995).

a. Teori absolut atau teori pembalasan

Menurut teori ini pidana diajtuhkan semata-mata karena orang telah melakukan kejahatan atau tindak pidana. Pidana merupakan akibat mutlak yang harus ada sebagai pembalsan kepada orang yang telah melakukan kejahatan. Adapun yang menjadi dasar pembenar dari penjatuhan pidana itu terletak pada adanya kejahatan itu sendiri, oleh karena itu pidana mempunyai fungsi untuk menghilangkan kejahatan tersebut.

b. Teori Relatif atau teori tujuan

Menurut teori ini penjatuhan pidana bukanlah sekedar untuk melakukan pembalasan atau pengimbalan. Pembalsan itu sendiri tidak mempunyai nilai tetapi hanya sebagai sarana melindungi kepentingan masyarakat. Teori ini berbeda dari teori absolut, dasar pemikiran agar suatu kejahatan dapat dijatuhi hukuman artinya penjatuhan pidana mempunyai tujuan tertentu, misalnya memperbaiki sikap mental atau membuat pelaku tidak berbahaya lagi, dibutuhkan proses pembinaan sikap mental.

c. Teori gabungan

Selain teroi absolut dan teori relatif juga ada teori ketiga yang disebut teori gabungan. Teori ini muncul sebagai reaksi dari teori sebelumnya yang kurang dapat memuaskan menjawab mengenai tujuan dari pemidanaan.

Tujuan pemidanaan dalam RUKHP dalam Pasal 54 yang menyatakan bahawa pemidanaan bertujuan :

a. Mencegah dilakukannya tindak pidana dengan menegakkan norma hukum demi pengayoman masyarakat;

b. Memasyarakatkan terpidana dengan megadakan pembinaan sehingga menjadi orang yang baik dan berguna;

c. Menyelesaikan konflik yang ditimbulkan oleh tindak pidana, memulihkan keseimbangan dan mendatangkan rasa damai dalam masyarkat; dan

d. Membebaskan rasa bersalah pada terpidana.

Pada hakikatnya pengertian hakim tercantum dalam KUHAP, yang 
menyebutkan hakim adalah pejabat peradilan Negara yang diberi wewenang oleh undang-undang untuk mengadili. Sedangkan yang dimaksud dengan mengadili adalah serangkaian tindakan hakim untuk menerima, memeriksa dan memutus perkara pidana berdasarkan asas bebas, jujur dan tidak memihak di sidang pengadilan dlaam hal menurut cara yang diatur dalam Undang-Undang (Pasal 1 ayat (9) KUHAP).

Putusan pengadilan atau putusan hakim pada dasarnya memiliki 3 (tiga) macam putusan yang akan diberikan kepada terdakwa di akhir persidangan, adapun jenisjenis putusan tersebut adalah sebagai berikut

\section{a. Putusan bebas}

Ini terjadi jika pengadilan berpendapat bahwa dari hasil pemeriksaan disidang, keslaahan terdakwa atas perbuatan yang didakwakan kepadanya tidak terbukti secara sah dan meyakinkan (Pasal 191 ayat (1)).

b. Putusan lepas dari segala tuntutan

Jika pengadilan berpendapat bahwa perbuatan yang didakwakan kepada terdakwa terbukti, tetapi perbuatan itu tidak merupakan suatu tindak pidana (Pasal 191 ayat (2)).

c. Putusan pemidanaan

Jika pengadilan berpendapat bahwa terdakwa bersalah melakukan tindak pidana yang didakwakan kepadanya, maka pengadilan menjatuhkan pidana (Pasal 193 ayat (1)).

Aspek "pertimbangan-pertimbangan yuridis terhadap pelaku tindak pidana yang didakwakan" merupakan konteks penting dalam putusan hakim(Mulyadi, n.d.). Padaa hakikatnya pertimbangan yuridis merupakan pembuktian unsur-unsur (bestendallen) dari suatu tindak pidana apakah perbuatan terdakwa tersebut telah memenuhi dan sesuai dengan tindak pidana yang didakwakan oleh jaksa/penuntut umum. Dapat diaktan lebih jauh bawa pertimbangan-pertimbangan yuridis ini secara langsung akan berpengaruh bersar terhadap amar/doktrin putusan hakim.

Lazimnya, dalam praktik peradilan pada putusan hakim sebelum "pertimbangan-pertimbangan yuridis" hakim akan menarik kesimpulan yang di dapat dari fakta-fakta di persidangan melalui keterangan para saksi, keterangan terdakwa, dan barang bukti yang diajukan dan diperiksa dipersidangan(Mulyadi, n.d.).

Berikut akan dijelaskan pertimbanganpertimbangan hakim yang bersifat yuridis dan Non yuridis :

1) Pertimbangan yang bersifat yuridis

Pertimbangan hakim yang didasarkan pada faktor-faktor yang terungkap dipersidangan dan oleh undang-undang telah ditetapkan sebagai hal yang harus 
dimuat dalam putusan, pertimbangan yuiridis diantaranya :

a. Dakwaan jaksa penuntut umum;

b. Keterangan saksi;

c. Keterangan terdakwa;

d. Pasal-pasal dalam undang-undang yang terkait.

2) Pertimbangan yang bersifat Non yuridis Selain pertimbangan yuridis hakim juga menggunakan pertimbangan non yuridis untuk menjadi dasar pertimbangannya :

a. Dampak dari perbuatan terdakwa.

b. Kondisi diri dari terdakwa.

Selain pertimbangan-pertimbangan yuridis dan non yuridis yang telah disebutkan diatas, terdapat hal yang meberatkan dan meringakan dalam hal penjatuhan pidana yang diberikan oleh hakim kepada terdakwa, hal-hal tersebut adalah sebagai berikut :

1) Hal-hal yang memberatkan pidana, yaitu :

a. Meresahkan masyarkat;

b. Sifat dari perbuatan terdakwa itu sendiri;

c. Akibat dari perbuatan yang ditimbulkan dari perbuatan terdakwa;

d. Terdakwa sudah pernah dihukum.

2) Hal-hal yang meringankan pidana, yaitu :

a. Belum pernah dihukum;

b. Menyesali perbuatannya;

c. Mengakui perbuatannya;

d. Bersikap sopan dipersidangan.
Faktor-faktor yang mempengaruhi hakim dalam pemidanaan terhadap terdakwa, dikarenakan perundang-undangan pidana yang ada di indonesia baik itu perundangan-undangan yang bersifat umum maupun yang bersifat khusus tidak mengatur secara tegas aturan batas minimum ancaman hukuman pidana bagi pelaku tindak pidana. Tidak adanya batas minimum inilah yang memberi keleluasaan hakim untuk menjatuhkan pidana. Sehinggan hal ini sering menimbulkan perbedaan hukuman atau sering disebut disparitas pidana.

Menurut Cheang Molly (Muladi dan Barda Nawawi Arief, 1998), disparity of sentencing atau disparitas pidana, adalah penerpan pidana yang tidak sama terhadap tindak pidana yang sama (same offence) atau terhadap tindak pidana yang sifat berbahayanya dapat diperbandingkan tanpa pembenaran yang jelas.

Sebagaimana telah disebutkan didalam bab pendahuluan terdahulu bahwa dalam putusan perkara pidana dikenal adanya suatu kesenjangan dalam penjatuhan pidana yang lebih dikenal dengan disparitas. Lebih spesifik dari pengertian itu, menurut Harkristuti Harkrisnowo disparitas pidana dapat terjadi dalam beberapa kategori yaitu:

a. Disparitas antara tindak pidana yang sama; 
b. Disparitas antara tindak pidana yang mempunyain tinfkat keseriusan yang sama;

c. Disparitas pidana yang dijatuhkan oleh satu majelis hakim;

d. Disparitas antara pidana yang dijatuhkan oelh majelis hakim yang berbeda untuk tindak pidana yang sama(Harkrisnowo, 2003).

Faktor-faktor yang mempengaruhi putusan hakim terdiri dari(Loqman, 2002):

a. faktor intern;

b. faktor pada undang-undang itu sendiri;

c. faktor penafsiran;

d. faktor politik; dan

e. faktor sosial.

Disparitas putusan dalam hal penjatuhan pidana diperbolehkan menurut pasal 12 huruf (a) KUHP yang menyatakan pidana penjara serendah-rendahnya 1 (satu) hari dan selama-lamanya seumur hidup. Disparitas pidana dapat diartikan sebagai penerapan pidana yang tidak sama terhadap tindak pidana yang sama (same offence) atau terhadap tindak-tindak pidana yang sifatnya berbahaya dapat diperbandingkan (offence of comparable seriousness) tanpa dasar pembenaran yang jelas(Muladi dan Barda Nawawi Arief, 2005).

Faktor yang dapat menyebabkan timbulnya disparitas pidana adalah tidak adanya pedoman pemidanaan bagi hakim dalam menjatuhkan pidana. Sudarto mengatakan bahwa pedoman pemberian pidana akan memudahkan hakim dalam menetapkan pemidanaannya, setekah terbukti bahwa terdakwa telah melakukan perbuatan yang didakwakan kepadanya(Sudarto, 1981).

Pedoman pemberian pidana itu memuat hal-hal yang bersifat objektif mengenai hal-hal yang berkaitan dengan si pelaku tindak pidana sehingga dengan memperhatikan hal-hal tersebut penjatuhan pidana lebih proporsional dan lebih dipahami mengapa pidananya seperti hasil putusan yang dijatuhkan oleh hakim. Pendapat Sudarto ini dibenarkan pula oleh Muladi, karena masalahnya bukan menghilangkan disparitas secara mutlak, tetapi disparitas tersebut harus rasional(Sudarto, 1981).

Faktor penyebab terjadinya disparitas pidana dapat ditinjau dari segi teoritis yuridis dan segi empiris. Dari segi teoritis yuridis, disparitas pidana disebabkan adanya

a. Eksistensi kebebasan dan kemandirian hakim dalam UUD RI 1945

Pengertian kekuasaan kehakiman yang bebas dan mandiri berdasarkan buku Pedeoman Perilaku Hakim (Code of Conduct) yang diterbitkan oleh Mahkamah Agung Republik Indonesia memuat serangkaian prinsip-prinsip dasar sebagai moralitas dan wajib dijunjung 
tinggi oleh para hakim di Indonesia baik di dalam maupun di luar kedinasannya(Mahkamah Agung RI, 2006).

b. UU Kekuasaan Kehakiman yang ada

Asas kebebasan hakim atau judicial discretionary power dijamin sepenuhnya dalam Pasal 1 UU No.48 Tahun 2009 Tentang Kekuasaan Kehakiman.

c. Teori Ratio Decidendi

Ratio Decidendi atau rationes decidenci adalah sebuah istilah latin yang sering diterjemahkan secara harfiah sebagai alasan untuk keputusan itu. Black's Law Dictionary menyatakan ratio decidendi sebagai "the point in a case which determines the judgement" atau menurut Barron's Law Dictionary adalah "the principle which the case establishes."(Huda, 2016)

\section{d. Teori Dissenting Opinion}

Dissenting Opinion menurut H.F Abraham Amos adalah perbedaan tentang amar putusan hukum dalam suatu kasus tertentu, dalam masyarakat yang majemuk dan multi kultur, perbedaan tentang pemahaman suatu hukum sudah menjadi hal yang biasa("Pengertian Dan Konsep Dissenting Opinion,” 2016).

e. Doktrin Res Judicate Pro Veritate Hebetur

Res Judicate Pro Veritate Hebetur, lazim disingkat Res Judicate berasal dari bahasa Latin "Res ludicata" yang berarti suatu yang telah diputuskan.

Black's Law Dictionary, sixth edition, merumuskan res judicata sebagai: " $A$ matter adjudged; a thing judicially acted upon or decided; a thing or matter settled by judgement. Rule that a final judgement renderd by a court of competent jurisdiction on the merits is conclusive as to the rights of the parties and their privies, an as to them, constitutes an absolute bar to a subsequent action involving the same claim, demand or cause of action".

(Black's Law Dictionary, sixth edition, merumuskan res judicata sebagai: "hal ini diputuskan, hal yang secara hukum ditindaklanjuti atau memutuskan. Sebuah hal atau masalah diselesaikan oleh penilaian. Aturan penilaian akhir yang diberikan oleh pengadilan dengan yurisdiksi yang kompeten pada manfaat meyakinkan mengenai hak-hak para pihak dan privat mereka, seperti mereka, yang merupakan hak yang mutlak untuk bertindak berikutnya melibatkan klaim permintaan atau penyebab tindakan.)

Dari segi empiris, pertimbangan kedaan terdakwa meliputi kepribadian, keadaan sosial, ekonomi, dan sikap masyarakat, serta dalam pembuktian fakta di persidangan juga dapat mempengaruhi pertimbangan hakim. Hakim sendiri tidak 
boleh memutus dalam keragu-raguan dan berprinsip pada in dubio proreo, sehingga muncul suatu disparitas pidana.

\section{Penutup}

\section{Kesimpulan}

Berdasarkan hasil penelitian dan pembahasan pada bab terdahulu maka dapat ditarik kesimpulan, bahwa faktor-faktor yang menjadi penyebab terjadinya disparitas dapat ditinjau dari segi teoritis yuridis dan segi empiris. Dari segi teoritis yuridis, disparitas pidana disebabkan adanya eksistensi kebebasan dan kemandirian yang dimiliki oleh hakim dalam UUD RI 1945 serta UU Kekuasaan Kehakiman yang ada, teori ratio decidendi, teori dissenting opinion, dan doktrin res judicate pro varitate hebeteur. Selain masalah yuridis yang disebutkan diatas faktor KUHP juga menjadi masalah dalam teoritis yuridis, dikarenakan KUHP tidak mengatur tentang minimal khusus penjatuhan pidana terhadap terdakwa. Dari segi empiris pertimbangan keadaan terdakwa meliputi kepribadian, keadaan sosial, ekonomi, dan sikap masyarakat, serta dalam pembuktian fakta di perisdangan juga dapat mempengaruhi pertimbangan hakim. Hakim sendiri tidak boleh memutus dalam keragu-raguan dan berprinsip pada in dubio proreo, sehingga muncul suatu disparitas pidana.
Kebebasan hakim juga merupakan faktor terjadinya disparitas pemidanaan. Di Indonesia asas kebebasan hakim (judicial discretionary power) dijamin sepenuhnya dalam Pasal 1 UU No.48 Tahun 2009 Tentang Kekuasaan Kehakiman. Dasar pertimbangan Hakim dalam penentuan pengambilan putusan hingga menyebabkan adanya disparitas pemidanaan pada perkara pidana, berdasarkan asas Nulla Poena Sine Lege hakim hanya dapat memutuskan sanksi pidana berdasarkan jenis dan berat sanksi sesuai dengan takaran yang ditentukan oleh Undang-Undang. Hambatan dan kesulitan lain yang ditemui hakim dalam menjatuhkan putusan pengadilan adalah kurang lengkapnya bukti materil yang diperlukan sebagai alat bukti dalam persidangan, serta proses pembuktian yang masih menggunakan metode tradisional atau konvensional dimana metode penjatuhan hukuman masih bertitik tolak pada keadaan pemeriksaan persidangan saja dikarenakan penentuan berat dan ringannya hukuman terdakwa masih dilakukan secara subjektif oleh hakim.

\section{Saran}

Salah satu tugas hakim adalah menggali nilai-nilai keadilan yang hidup dalam masyarakat, oleh karena itu hakim harus memperhatikan aspek disparitas penjatuhan pidana untuk memenuhi nilai keadilan 
substantif, serta dalam memutuskan suatu perkara sebaiknya hakim tidak hanya mendengarkan korban saja, tetapi juga harus tetap mendengarkan pembelaan dari terdakwa dan mempertimbangkannya agar hakim dapat bersifat seadil mungkin, dengan cara meninggalkan metode penjatuhan pidana yang bersifat tradisional atau konvensional tersebut.

Hal tersebut dapat dijadikan upaya untuk meminimalisir disparitas pemidanaan. Upaya untuk meminimalisir hal tersebut, maka penggunaan logika hukum menjadi sebuah solusi, yaitu dengan metode :

a. Merumuskan substansi hukum secara tepat;

b. Memahami kesesatan hukum (fallacies of law);

c. Pengunaan penalaran induksi dan deduksi secara tepat;dan

d. Penemuan dan penerpaan hukum.

Bagaimanapun disapritas pidana tidak dapat dihilangkan secara mutlak. Diperlukan suatu pedoman bagi hakim untuk menentukan jenis pemidanaan yang tepat untuk diajtuhkan kepada terdakwa, sehingga dengan adanya pedoman tersebut dapat mengedepankan transparansi dan konsistensi dalam menjatuhkan sanksi pidana sesuai dengan asas persumptive sentencing.

\section{DAFTAR PUSTAKA}

Harkrisnowo, H. (2003). Rekonstruksi Konsep Pemidanaan: Suatu Gugatan Terhadap Proses Legislasi dan Pemidanaan di Indonesia. Jakarta: Majalah KHN Newsletter.

Huda, M. (2016). titles Ratio Decidenci accessed in 20. Retrieved September 20 , 2016 , from http://miftakhulhuda.com/2011/03/rati odecidenci

Komisi Yudisial RI. (2014). Disparitas Putusan Hakim:Identifikasi dan Implikasi. Jakarta: Sekjen Komisi Yudisial RI.

Loqman, L. (2002). HAM dalam HAP. Jakarta: Datacom.

Mahkamah Agung RI. (2006). Pedoman Perilaku Hakim. Jakarta: Mahkamah Agung.

Marpaung, L. (2005). Asas-Teori-Praktik Hukum Pidana. Jakarta: Sinar Grafika.

Mertokusumo, S. (2007). Hati Nurani Hakim dan Putusannya, dalam Antonius Sudirman. Bandung: Citra Aditya Bakti.

Muladi. (1995). KAPITA Selekta Sistem Peradilan Pidana. UNDIP.

Muladi dan Barda Nawawi Arief. (1984). Teori-teori Dan Kebijakan Pidana. Bandung: Alumni.

Muladi dan Barda Nawawi Arief. (1998). Teori-teori Dan Kebijakan Pidana. 
Bandung: Alumni.

Muladi dan Barda Nawawi Arief. (2005).

Teori-teori Dan Kebijakan Pidana.

Bandung: Alumni.

Mulyadi, L. (n.d.). Seraut Wajah Putusan

Hakim Dalam Hukum Acara Pidana.

Citra Aditya Bhakti.

Pengertian Dan Konsep Dissenting Opinion.

(2016). Retrieved September 20, 2016,

from http://id.shvoong.com/law-and-

politics/administrative-law/2172112

Sudarto. (1981). Kapita Selekta Hukum

Pidana Indonesia. Bandung: Alumni.

Wijayanto, I. (2012). Disparitas Pidana

Dalam Perkara Tindak Pidana Biasa

Di Pengadilan Negeri Kota Semarang,

7, 208. 